\section{A Bibliometric Analysis of Articles Published in Brazilian Dental Journal over 30 years}

Rafael Ratto de Moraes $^{1,2}{ }^{\infty}$, Laura Lourenço Morel $^{1} \mathbb{D}^{-}$, Marcos Britto Correa $^{1,2}$, Giana da Silveira Lima ${ }^{1,2}$

\begin{abstract}
This study assessed bibliometric characteristics of all articles published in Brazilian Dental Journal (BDJ) in its 30 years of existence (1990-2019) and factors associated with citation rates. A document search was carried out in Scopus in December, 2019 and information about the articles were exported, including citations. Type of study and main subject in each article were categorized. Number of citations was categorized in tertiles. Logistic regression models were used to assess the association between variables related to articles' characteristics and number of citations. In 30 years, 1705 articles were published and 18507 citations received, with average 57 articles and 334 pages published yearly and 10.9 cites/doc. The most frequent types of study were laboratorial (63\%), clinical (18.5\%), and case reports $(11 \%)$; the main subjects were dental materials $(21.6 \%)$, endodontics (19.3\%), and oral pathology/stomatology (13.1\%). Most articles had origin in Brazil (90\%), followed by USA (4.6\%) and UK (1.5\%). Aside from BDJ, Journal of Endodontics (3.5\%) and International Endodontic Journal (2.2\%) were journals that most often cited BDJ. Main origins of citations were Brazil (36.7\%), USA (10.6\%), and India (9\%). Older articles had higher odds to be highly cited ( $12 \%$ increase/year), longer articles had lower odds ( $9 \%$ decrease/page). Narrative reviews and epidemiological studies were associated with more citations and systematic reviews with less citations. In conclusion, BDJ covered many subjects and study types in 30 years, showing increased growth in international audience. The journal may be regarded as one of the leading Brazilian journals in dentistry published in English.
\end{abstract}

1School of Dentistry, UFPEL - Universidade Federal de Pelotas, Pelotas, RS, Brazil 2Graduate Program in Dentistry, UFPEL - Universidade Federal de Pelotas, Pelotas, RS, Brazil

Correspondence: Prof. Rafael Moraes, Rua Gonçalves Chaves 457, room 505, 96015-560 Pelotas, RS, Brasil. Tel: +55-53-3260-2831. e-mail: rafael.moraes@ufpel.edu.br

\section{Introduction}

Brazil is the second country with most dental articles published yearly since 2006, according to Scimago Journal \& Country Rank (1), which is powered by the Scopus database. In 2018, 2,218 international articles were published by authors affiliated to Brazil. Those articles gathered 873 citations (386 self-citations), reflecting a 0.39 cites per document rate. This citation rate is only fifth amongst the top-10 publishing countries in dentistry. However, in 1999 Brazil published 142 articles, reflecting an overwhelming 1,460\% increase in international dental articles published in two decades. Considering the year 1999, the Brazilian Dental Journal (BDJ) was the only journal from Brazil listed in Scimago Ranks for the category Dentistry. In contrast, 10 international dental journals from Brazil were present in the list in 2018, with $\mathrm{H}$-indexes varying from 2 to 48 (BDJ is highest). The remarkable increase in international science output from Brazil in the last two decades has been discussed before $(2,3)$ and there are many factors and variables involved in the process. Concurrently, BDJ has experienced many changes as a journal since its first issue in 1990, including increase in subjects covered and types of study published, growth in international audience and in number of articles published yearly. In its three decades of existence, BDJ has contributed significantly to the dental science as one of the main sources for dissemination of the Brazilian research in dentistry. In celebration to the 30 years of $B D J$, this study assessed bibliometric characteristics of all articles published in BDJ in its 30 years of existence (1990-2019) and factors associated with citation rates.

\section{Material and Methods}

In this retrospective longitudinal study, a document search for the articles published in BDJ was carried out in Scopus in December, 2019 including the full 2019 record. A census was carried out with all articles, no exclusion criterion was used. Information about the articles were exported from the database to a comma separated value file, including the following variables: authors, authors' affiliations, document title, year, volume, issue, number of pages, citation counts (including self-citations but not separate), and funding text. Funding was categorized as present or absent. By assessing titles and abstracts (and fulltexts when necessary), the type of study was categorized as 
case report, clinical, epidemiological, laboratorial, narrative review, qualitative/survey/questionnaire, systematic review/ metanalysis, or other, when the study did not match any of the previous types. The main subject addressed by the article also was categorized: basic science (e.g. cell biology, genetics, microbiology), dental education, dental materials, endodontics, implantology, operative dentistry/ cariology, oral and maxillofacial surgery, oral pathology/ stomatology, oral radiology, orthodontics, pediatric dentistry, periodontology, prosthodontics/occlusion, public health/epidemiology, or other (3). Additional information regarding all articles published during the 30 years of BDJ were obtained in Scopus: top publishing authors and institutions, main funding sponsors, top cited articles, and country of origin of articles and citations. Data were analyzed descriptively. In addition, number of citations per article was collected and categorized in three groups according to tertiles distribution: 0 to three citations; four to 10 citations and; more than 10 citations, generating an ordinal variable used as outcome. Ordered Logistic Regression models were used to assess the association between variables related to articles' characteristics and number of citations. Results were expressed in odds ratios $(\mathrm{OR})$ and 95\% confidence intervals (Cl). Analyses were performed using software Stata 14.2 (StataCorp. College Station, Texas, USA).

\section{Results and Discussion}

As shown in Table 1, a total of 1705 articles was published between 1990-2019, with 18507 citations received by 15080 unique documents, with an average 57 articles and 334 pages published yearly, 10.9 citations per document published, and $\mathrm{H}$-index $=48$. The year with best average cites/doc was 2002, but the year with most unique articles citing BDJ irrespective of the year of publication of the article cited was 2018, indicating that BDJ is gathering more attention from other journals in the literature in recent years. In fact, the number of documents citing BDJ articles increased each year. Figure 1 shows the three main subjects addressed in articles published each year since the first issue of BDJ. One can notice that endodontics (26 times), dental materials (20 times), and oral pathology/stomatology (19 times) were the subjects most frequently addressed yearly, although variations depending on the year of publication were present. For instance, oral and maxillofacial surgery appeared in top-3 subjects in seven years, periodontology in six years, and operative dentistry/cariology in four years. This analysis indicates that BDJ in fact is a multidisciplinary journal, although with higher number of articles and citations in some subjects compared to others.

Table 2 presents the distribution of articles and citations by type of study, main subject addressed by the article, and presence/absence of funding text. The three most frequent types of study published in BDJ in 30 years were laboratorial studies (63\%), clinical studies (18.5\%), and case reports (11\%). For the different types of study, the two highest cites/ doc were observed for narrative reviews and epidemiological studies. For the different subjects, the two highest cites/ doc were observed for public health/epidemiology and endodontics. The three main subjects addressed in articles were dental materials (21.6\%), endodontics (19.3\%), and

Table 1 . Articles and pages published yearly, citations gathered by articles, cites/doc, and number documents citing the articles

\begin{tabular}{|c|c|c|c|c|c|}
\hline Year & Articles & Pages & Citations* & Cites/doc & $\begin{array}{l}\text { Cited } \\
\text { by** }\end{array}$ \\
\hline 1990 & 7 & 48 & 35 & 5.0 & NA \\
\hline 1991 & 10 & 71 & 67 & 6.7 & NA \\
\hline 1992 & 18 & 122 & 207 & 11.5 & NA \\
\hline 1993 & 15 & 99 & 195 & 13.0 & NA \\
\hline 1994 & 22 & 127 & 163 & 7.4 & NA \\
\hline 1995 & 22 & 129 & 291 & 13.2 & 1 \\
\hline 1996 & 17 & 102 & 189 & 11.1 & 1 \\
\hline 1997 & 17 & 103 & 136 & 8.0 & 6 \\
\hline 1998 & 17 & 104 & 177 & 10.4 & 15 \\
\hline 1999 & 17 & 104 & 160 & 9.4 & 12 \\
\hline 2000 & 22 & 151 & 386 & 17.5 & 22 \\
\hline 2001 & 44 & 195 & 801 & 18.2 & 25 \\
\hline 2002 & 40 & 201 & 1046 & 26.2 & 44 \\
\hline 2003 & 41 & 211 & 885 & 21.6 & 77 \\
\hline 2004 & 49 & 270 & 983 & 20.1 & 119 \\
\hline 2005 & 44 & 247 & 917 & 20.8 & 178 \\
\hline 2006 & 67 & 336 & 1230 & 18.4 & 242 \\
\hline 2007 & 65 & 338 & 1106 & 17.0 & 319 \\
\hline 2008 & 60 & 336 & 1115 & 18.6 & 406 \\
\hline 2009 & 74 & 420 & 1068 & 14.4 & 550 \\
\hline 2010 & 85 & 504 & 1409 & 16.6 & 645 \\
\hline 2011 & 88 & 505 & 1230 & 14.0 & 852 \\
\hline 2012 & 119 & 716 & 1366 & 11.5 & 1051 \\
\hline 2013 & 114 & 644 & 981 & 8.6 & 1120 \\
\hline 2014 & 100 & 563 & 702 & 7.0 & 1255 \\
\hline 2015 & 120 & 682 & 671 & 5.6 & 1389 \\
\hline 2016 & 130 & 765 & 609 & 4.7 & 1499 \\
\hline 2017 & 111 & 734 & 267 & 2.4 & 1618 \\
\hline 2018 & 88 & 601 & 108 & 1.2 & 1834 \\
\hline 2019 & 82 & 586 & 7 & 0.1 & 1800 \\
\hline Total & 1705 & 10014 & 18507 & - & 15080 \\
\hline Average & 57 & 334 & 617 & 11 & 603 \\
\hline
\end{tabular}

NA: data not available in Scopus for those years. *Number of citations gathered by year of publication. ${ }^{* *}$ Number of unique documents citing the articles. 
oral pathology/stomatology (13.1\%), which is in line with data shown in Figure 1. In addition, it has been shown that Brazil is a great contributor to the international dental materials science output, with a substantial number of articles and patents published yearly (4). Interestingly, the presence of funding text was not high in the sample, only $1.4 \%$ of articles, with an average 1.4 cites/doc. One should notice that the absence of funding text in the database may not actually mean that the study was not funded since we notice a very low frequency of sponsors mentioned in Scopus. We believe that the low number of studies considered funded by the database could be explained by problems of Scopus in identifying Brazilian funding agencies.

Table 3 presents the top- 10 authors, top-10 affiliations, top-10 origin of articles (countries), top- 5 funding sponsors, top-10 citing journals, and top- 5 origin of citations from all articles published in the 30 years of BDJ. Three main publishing authors were JD Pecora (4.3\%), C Estrela $(2.6 \%)$, and L Correr-Sobrinho (2.2\%), whereas three main affiliations were all from the Brazilian São Paulo state: University of São Paulo (USP, 34.5\%), considering all USP campi, State University of Campinas (UNICAMP, 14.7\%), and all UNESP campi together. Most articles published by BDJ had origin in Brazil (90\%), which was followed by USA (4.6\%) and UK (1.5\%). Main funding sponsors were CNPq/ Brazil and FAPESP/Brazil (3.5\% each). BDJ is the journal that most often cite BDJ articles, which is something expected in every journal worldwide. Aside from BDJ, Journal of Endodontics (3.5\% of unique documents) and International Endodontic Journal (2.2\%) were journals that most often cited BDJ papers. This finding is in line with the observations that endodontics is a subject very often published in BDJ that shows one of the highest citation rates among subjects published in the journal. Other journals with good bibliometrics and international audience are in the top-10 list of main citing journals. Main origins of those citations (author affiliations) were Brazil (36.7\%), USA (10.6\%), and India (9\%). These numbers indicate that despite the national character in the title of BDJ, and that most articles published were originated in Brazil, only $1 / 3$ of all citations gathered by those articles derived from articles published by Brazilian authors, reflecting again that BDJ has a very good international audience and may be regarded effectively as an international journal.

The 30 top cited articles published in BDJ are listed in Table 4 (5-34). Number of citations varied between 238

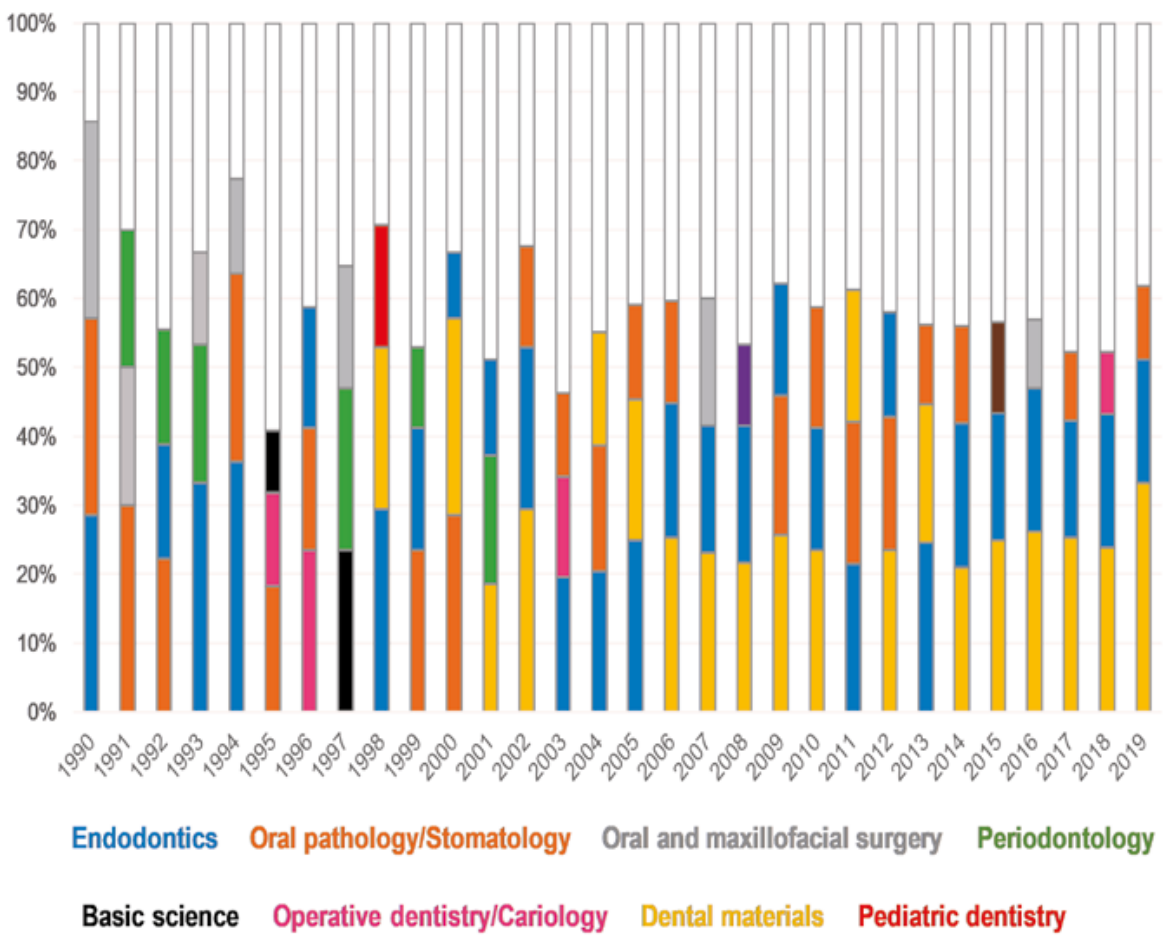

Prosthodontics/Occlusion Implantology

Figure 1. Main three subjects addressed in articles yearly. White bars refer to all other topics published in that year. One can notice that endodontics (26 times), dental materials (20 times), and oral pathology/stomatology (19 times) were the subjects most frequently addressed yearly, although variations depending on the year of publication were present. For instance, oral and maxillofacial surgery appeared in top-3 subjects in seven years, periodontology in six years, and operative dentistry/cariology in four years. 
and 60, the most recent article was published in 2013, the oldest was published in 1992. Two authors (Estrela and Holland) have respectively five and three papers as first authors in the top-30 cited list. The main subject of articles in the top-30 citation list was endodontics (43\%), reinforcing it as one of the main topics published by BDJ and also that endodontics perhaps is the subject that gathers most attention from international authors and journals among all others. Figure 2 shows tag clouds for terms in article titles from all articles in the sample. This is an interesting and simple way of observing which specific terms are most frequently quoted in BDJ articles and, in turn, most frequent topics covered, including experimental methods. The most frequent terms found in titles included common and expected words such as effect, evaluation, influence, study, dental, oral, enamel, dentin, analysis, and Brazilian. Words related to types of study were also frequent, including case, report, clinical, and trial. Other terms frequently reported were related to the subjects addressed by the articles, such as terms often related to endodontics (root, canal, systems) and dental materials (cement, acid, strength, resin, adhesive). Other terms frequently quoted were bone, laser, denture, stress, rats, glass, and repair, among others.

Table 5 shows the results of association between characteristics of articles and citations. Regarding the year since publication, the odds of being in higher cited groups increase $12 \%$ per each additional year. This is expected since older articles in the literature have higher chance of being cited than newer articles (3). The number of pages was negatively associated with citations: each additional page decreases in 9\% the odds of the article being in highly cited groups. This is a very interesting finding that perhaps is difficult to explain, although we speculate that longer articles may be less reader friendly. If the reader loses the interest in the article, the chance of quoting it in a future paper may be lower. It has been shown that journals which
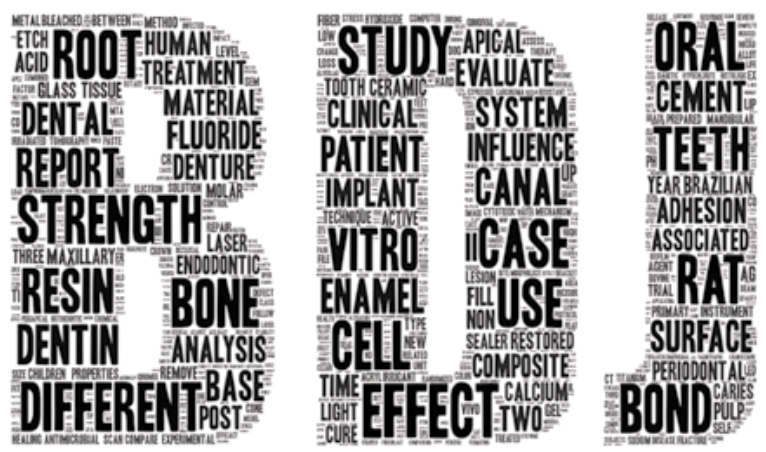

Figure 2. Tag cloud for words in titles of all articles published between 1990 and 2019. Bigger words mean more frequent mentions in titles. publish papers with shorter titles receive more citations per paper (35); the authors of the study hypothesized that shorter titles may be easier to understand and attract more citations. If longer titles lead to lower citations, perhaps the same could happen with longer articles, as observed here. Presence of funding text was associated with a reduction on citations, but caution should be used when interpreting this finding because, as explained before, we believe that issues regarding funding information are present in the Scopus database. A recent study (3) observed that presence

Table 2. Distribution of articles and citations by type of study, main subject and presence or absence of funding text $(n=1705$ articles, 18507 citations)

\begin{tabular}{|c|c|c|c|}
\hline & \multirow{2}{*}{$\begin{array}{l}\text { Articles, } \\
\text { n (\%) }\end{array}$} & \multicolumn{2}{|c|}{ Citations } \\
\hline & & Total, $\mathrm{n}$ & Cites/doc \\
\hline \multicolumn{4}{|l|}{ Type of study } \\
\hline Case report & $187(11.0)$ & 1479 & 7.9 \\
\hline Clinical & $315(18.5)$ & 2899 & 9.2 \\
\hline Epidemiological & $14(0.8)$ & 312 & 22.3 \\
\hline Laboratorial & $1073(62.9)$ & 12081 & 11.3 \\
\hline Narrative review & $31(1.8)$ & 772 & 24.9 \\
\hline $\begin{array}{l}\text { Qualitative/survey/ } \\
\text { questionnaire }\end{array}$ & $50(2.9)$ & 544 & 10.9 \\
\hline $\begin{array}{l}\text { Systematic review/ } \\
\text { meta-analysis }\end{array}$ & $13(0.8)$ & 33 & 2.5 \\
\hline Other & $22(1.3)$ & 387 & 17.6 \\
\hline \multicolumn{4}{|l|}{ Subject } \\
\hline Basic science & $96(5.6)$ & 295 & 7.8 \\
\hline Dental education & $9(0.5)$ & 63 & 7.0 \\
\hline Dental materials & $368(21.6)$ & 3891 & 10.6 \\
\hline Endodontics & $329(19.3)$ & 4566 & 14.0 \\
\hline Implantology & $90(5.3)$ & 883 & 9.8 \\
\hline $\begin{array}{c}\text { Operative } \\
\text { dentistry/Cariology }\end{array}$ & $122(7.2)$ & 1384 & 11.3 \\
\hline $\begin{array}{l}\text { Oral and } \\
\text { maxillofacial surgery }\end{array}$ & $118(6.9)$ & 1381 & 11.7 \\
\hline $\begin{array}{l}\text { Oral pathology/ } \\
\text { Stomatology }\end{array}$ & $224(13.1)$ & 2076 & 9.3 \\
\hline Oral radiology & $33(1.9)$ & 313 & 9.5 \\
\hline Orthodontics & $34(2.0)$ & 211 & 6.2 \\
\hline Pediatric dentistry & $51(3.0)$ & 592 & 11.6 \\
\hline Periodontology & $114(6.7)$ & 722 & 6.3 \\
\hline $\begin{array}{l}\text { Prosthodontics/ } \\
\text { Occlusion }\end{array}$ & $74(4.3)$ & 797 & 10.8 \\
\hline $\begin{array}{l}\text { Public health/ } \\
\text { Epidemiology }\end{array}$ & $18(1.1)$ & 322 & 17.8 \\
\hline Other & $25(1.5)$ & 198 & 7.9 \\
\hline \multicolumn{4}{|l|}{ Funding text } \\
\hline No & $1151(91.0)$ & 18293 & 15.9 \\
\hline Yes & $154(9.0)$ & 214 & 1.4 \\
\hline
\end{tabular}


Table 3. Main authors, affiliations, origins, funders, citing journals, and origins of citations for 1,705 articles with 18,507 citations received from 15,114 unique documents

\begin{tabular}{lcc}
\hline & $\mathrm{n}$ & $\%$ \\
\hline Top-10 authors & & \\
Pecora JD & 73 & 4.3 \\
Estrela C & 45 & 2.6 \\
Correr-Sobrinho L & 38 & 2.2 \\
Sinhoreti MA & 36 & 2.1 \\
Sousa-Neto MD & 32 & 1.9 \\
Novaes Jr. AB & 30 & 1.8 \\
Silva-Sousa YT & 30 & 1.8 \\
Demarco FF & 28 & 1.6 \\
Soares CJ & 28 & 1.6 \\
Consani S & 24 & 1.4
\end{tabular}

Top-10 author affiliations*

Universidade de São Paulo

$587 \quad 34.5$

Universidade Estadual de Campinas

250

14.7

Universidade Estadual Paulista

Universidade Federal de Pelotas

Universidade Federal de Uberlândia

Universidade de Ribeirão Preto

Universidade Federal de Goiás

Universidade Federal de Minas Gerais

Universidade Federal do Rio Grande do Sul

Universidade Federal Fluminense

$241 \quad 14.2$

$73 \quad 4.3$

$62 \quad 3.6$

$62 \quad 3.6$

$61 \quad 3.6$

$60 \quad 3.5$

$53 \quad 3.1$

$47 \quad 2.8$

Top-10 origin of articles*

United States

United Kingdom

Turkey

Canada

Italy

Spain

India

Iran

Portugal
Table 3. Main authors, affiliations, origins, funders, citing journals, and origins of citations for 1,705 articles with 18,507 citations received from 15,114 unique document (cont.)

\begin{tabular}{lcc}
\hline & $\mathrm{n}$ & $\%$ \\
\hline Top-10 citing journals*** & & \\
Brazilian Dental Journal & 702 & 4.6 \\
Journal of Endodontics & 524 & 3.5 \\
International Endodontic Journal & 340 & 2.2 \\
Journal of Applied Oral Science & 274 & 1.8 \\
Clinical Oral Investigations & 227 & 1.5 \\
Operative Dentistry & 197 & 1.3 \\
Journal of Prosthetic Dentistry & 172 & 1.1 \\
Journal of Contemporary Dental Practice & 169 & 1.1 \\
Journal of Dentistry & 150 & 1.0 \\
Lasers in Medical Science & 147 & 1.0 \\
Top-10 origins of citations** & & \\
Brazil & & \\
United States & 5542 & 36.7 \\
India & 1609 & 10.6 \\
Turkey & 1348 & 8.9 \\
Iran & 908 & 6.0 \\
China & 780 & 5.2 \\
Italy & 696 & 4.6 \\
Germany & 585 & 3.9 \\
Saudi Arabia & 530 & 3.5 \\
\hline & 480 & 3.2 \\
& 358 & 2.4 \\
\hline
\end{tabular}

Data retrieved December 16, 2019. *Accounts for multiple institutions and origins.*** Relative to documents.

Top-5 funding sponsors

$\begin{array}{lll}\text { CNPq } & 60 & 3.5 \\ \text { FAPESP } & 60 & 3.5 \\ \text { CAPES } & 58 & 3.4 \\ \text { FAPEMIG } & 17 & 1.0 \\ \text { FAPERJ } & 10 & 0.6\end{array}$


of funding did not influence citation rates of dental articles with authors from Brazil. Another bibliometric study observed that citations are more closely associated with the nationality of authors than funding itself (36).

Regarding the type of study, compared with case reports, the odds of being highly cited was higher in Narrative reviews and Epidemiological studies. Systematic reviews/Meta-analysis presented lower odds of being cited compared with case reports. BDJ did not publish many systematic reviews in its 30 years of existence, the average

Table 4. Top-30 cited articles published in BDJ between 1990 and 2019

\begin{tabular}{|c|c|c|}
\hline First author, title & Year & Citations \\
\hline Estrela et al, Mechanism of action of sodium hypochlorite & 2002 & 238 \\
\hline Estrela et al, Antimicrobial and chemical study of MTA, Portland cement, calcium hydroxide paste, Sealapex and Dycal & 2000 & 190 \\
\hline Novaes Jr et al, Influence of implant surfaces on osseointegration & 2010 & 139 \\
\hline Estrela et al, Mechanism of action of calcium and hydroxyl ions of calcium hydroxide on tissue and bacteria & 1995 & 134 \\
\hline Aidar \& Line, A simple and cost-effective protocol for DNA isolation from buccal epithelial cells & 2007 & 133 \\
\hline $\begin{array}{l}\text { Holland et al, Healing process of dog dental pulp after pulpotomy and pulp } \\
\text { covering with mineral trioxide aggregate or Portland cement }\end{array}$ & 2001 & 133 \\
\hline López et al, Salivary characteristics of diabetic children & 2003 & 109 \\
\hline $\begin{array}{l}\text { Holland et al, Reaction of rat connective tissue to implanted dentin tube filled with } \\
\text { mineral trioxide aggregate, Portland cement or calcium hydroxide }\end{array}$ & 2001 & 104 \\
\hline Queiroz et al, pH-Cycling models to evaluate the effect of low fluoride dentifrice on enamel de- and remineralization & 2008 & 99 \\
\hline Cury et al, The importance of fluoride dentifrices to the current dental caries prevalence in Brazil & 2004 & 95 \\
\hline $\begin{array}{l}\text { Gajewski et al, Monomers used in resin composites: Degree of conversion, } \\
\text { mechanical properties and water sorption/solubility }\end{array}$ & 2012 & 94 \\
\hline Estrela et al, Mesenchymal stem cells in the dental tissues: Perspectives for tissue regeneration & 2011 & 92 \\
\hline Rosa \& Beloti, Effect of cpTi surface roughness on human bone marrow cell attachment, proliferation, and differentiation & 2003 & 90 \\
\hline Shinohara et al, Oral myiasis treated with ivermectin: Case report & 2004 & 86 \\
\hline $\begin{array}{l}\text { Vasconcelos et al, Minimum inhibitory concentration of adherence of Punica granatum } \\
\text { Linn (pomegranate) gel against S. mutans, S. mitis and C. albicans }\end{array}$ & 2006 & 84 \\
\hline Ladalardo et al, Laser therapy in the treatment of dentine hypersensitivity & 2004 & 83 \\
\hline Garcia et al, Antioxidant activity by DPPH assay of potential solutions to be applied on bleached teeth & 2012 & 82 \\
\hline Gomes et al, Chlorhexidine in endodontics & 2013 & 78 \\
\hline $\begin{array}{l}\text { Zogheib et al, Effect of hydrofluoric acid etching duration on the roughness and } \\
\text { flexural strength of a lithium disilicate-based glass ceramic }\end{array}$ & 2011 & 77 \\
\hline Pinheiro et al, Effect of low level laser therapy on the repair of bone defects grafted with inorganic bovine bone. & 2003 & 74 \\
\hline Pecora et al, Morphologic study of the maxillary molars. Part II: Internal anatomy & 1992 & 74 \\
\hline Nunes et al, Adhesion of epiphany and AH plus sealers to human root dentin treated with different solutions & 2008 & 73 \\
\hline Durack \& Patel, Cone beam computed tomography in endodontics & 2012 & 72 \\
\hline Estrela et al, Antimicrobial effect of $2 \%$ sodium hypochlorite and $2 \%$ chlorhexidine tested by different methods & 2003 & 72 \\
\hline Demarco et al, Dental pulp tissue engineering & 2011 & 66 \\
\hline da Silva et al, Improvement of XTT assay performance for studies involving Candida albicans biofilms & 2008 & 65 \\
\hline Siqueira Jr \& Roças, Bacterial pathogenesis and mediators in apical periodontitis & 2007 & 64 \\
\hline $\begin{array}{l}\text { Pereira et al, Antimicrobial activity of Arctium lappa constituents against } \\
\text { microorganisms commonly found in endodontic infections }\end{array}$ & 2005 & 61 \\
\hline de Oliveira et al, Comparative chemical study of MTA and Portland cements & 2007 & 60 \\
\hline Holland et al, Reaction of rat connective tissue to implanted dentin tubes filled with a white mineral trioxide aggreg & 2002 & 60 \\
\hline
\end{tabular}

Data accessed December, 2019. 
is less than 1 every other year. The dental literature has recently experience a significant increase in number of systematic reviews published $(37)$. Some authors $(38,39)$ in fact have criticized the number and quality of systematic reviews published in health sciences because of their low impact in healthcare. Anyway, articles reporting systematic reviews are usually well cited but that was not the case for BDJ. Finally, the subject of article was also associated with citation rates. Articles on dental materials, basic science, endodontics, operative dentistry/cariology, oral pathology/ stomatology, oral and maxillofacial surgery, prosthodontics/ occlusion, and public health/epidemiology were associated with higher odds of being cited compared with articles on periodontology, which was used as reference in the analysis. These results reinforce the observation that BDJ is a multidisciplinary journal that attracts attention from authors and journals of different country origins publishing on distinct subject areas.

In conclusion, BDJ covered many subjects and study types in its 30 years of publication. Narrative reviews and epidemiological studies are the study types associated with higher odds of being cited, whereas endodontics, dental materials, and oral pathology/stomatology were the subjects most often addressed in the articles. The increasing

Table 5. Association between citations of articles and interest variables. Ordered Logistic Regression. ( $\mathrm{n}=1705)$

\begin{tabular}{|c|c|c|}
\hline Variable & Odds Ratio (95\% CI) & $\mathrm{p}$ value \\
\hline Years since publication (numeric) & $1.12(1.11 ; 1.14)$ & $<0.001$ \\
\hline Number of pages (numeric) & $0.91(0.86 ; 0.96)$ & 0.001 \\
\hline Funding text (ref. absent) & $0.06(0.04 ; 0.09)$ & $<0.001$ \\
\hline Type of article (ref. Case report) & & $<0.001$ \\
\hline Clinical & $0.96(0.69 ; 1.33)$ & \\
\hline Epidemiological & $1.94(0.66 ; 5.68)$ & \\
\hline Laboratorial & $1.25(0.94 ; 1.65)$ & \\
\hline Narrative Review & $3.45(1.64 ; 7.27)$ & \\
\hline Qualitative/Survey/Questionnaire & $1.88(1.03 ; 3.40)$ & \\
\hline Systematic Review/Meta-analysis & $0.18(0.05 ; 0.67)$ & \\
\hline Other & $0.57(0.23 ; 1.39)$ & \\
\hline Topic of article (ref. Periodontology) & & 0.006 \\
\hline Basic science & $1.65(1.00 ; 2.72)$ & \\
\hline Dental education & $1.18(0.33 ; 4.14)$ & \\
\hline Dental materials & $1.61(1.09 ; 2.38)$ & \\
\hline Endodontics & $2.18(1.47 ; 3.25)$ & \\
\hline Implantology & $1.09(0.65 ; 1.83)$ & \\
\hline Operative dentistry/Cariology & $1.69(1.05 ; 2.73)$ & \\
\hline Oral pathology/Stomatology & $2.03(1.33 ; 3.07)$ & \\
\hline Oral radiology & $1.24(0.59 ; 2.61)$ & \\
\hline Oral and maxillofacial surgery & $2.20(1.38 ; 3.53)$ & \\
\hline Orthodontics & $1.18(0.59 ; 2.36)$ & \\
\hline Other & $1.06(0.48 ; 2.34)$ & \\
\hline Pediatric dentistry & $1.70(0.92 ; 3.13)$ & \\
\hline Prosthodontics/Occlusion & $1.94(1.14 ; 3.34)$ & \\
\hline Public health/Epidemiology & $2.56(1.00 ; 6.62)$ & \\
\hline
\end{tabular}

CI: confidence interval. 
growth in international audience of BDJ and its current bibliometric indicators suggest that the next decade will be a period for consolidation of its leadership as one of the main Brazilian journals in dentistry published in English.

\section{Resumo}

Este estudo avaliou as caracteristicas bibliométricas de todos os artigos publicados no Brazilian Dental Journal (BDJ) em seus 30 anos de existência (1990-2019) e fatores associados com taxas de citação. Uma busca pelos documentos foi realizada no Scopus em Dezembro de 2019 e informações acerca dos artigos foram exportadas, incluindo citações. Tipo de estudo e principal assunto em cada artigo foram categorizados. Número de citações foi categorizado em tercis. Modelos de regressão logística foram usados para avaliar a associação entre as variáveis relacionadas às características dos artigos e o número de citações. Em 30 anos, 1705 artigos foram publicados e 18507 citações recebidas, com média de 57 artigos e 334 páginas publicadas ao ano e 10,9 citações/documento. Os tipos de estudo mais frequentes foram laboratorial (63\%), clínico $(18,5 \%)$ e relato de caso (11\%); os principais assuntos foram materiais dentários $(21,6 \%)$, endodontia $(19,3 \%)$ e patologia oral/estomatologia $(13,1 \%)$. A maioria doas artigos teve origem do Brasil (90\%), seguido dos EUA $(4,6 \%)$ e Reino Unido (1,5\%). Além do BDJ, Journal of Endodontics $(3,5 \%)$ e International Endodontic Journal $(2,2 \%)$ foram os periódicos que mais citaram o BDJ. As principais origem das citações foram Brasil (36,7\%), EUA $(10,6 \%)$ e Índia (9\%). Artigos mais antigos tiveram maiores chances de serem altamente citados (aumento de 12\% ao ano), artigos mais longos tiveram menores chances (redução de $9 \%$ por página). Revisões narrativas e estudos epidemiológicos foram associados com mais citações e revisões sistemáticas com menos citações. Em conclusão, o BDJ cobriu diversos assuntos e tipos de estudo em 30 anos, mostrando contínuo crescimento na audiência internacional. 0 periódico pode ser considerado um dos lideres entre as revistas brasileiras de odontologia publicadas em inglês.

\section{Acknowledgments}

This study was financed in part by the Coordenação de Aperfeiçoamento de Pessoal de Nível Superior (CAPES), Brazil (Finance Code 001).

\section{References}

1. Scimago Journal \&t Country Rank. Available from: www.scimagojr.com [Latest access January 2020].

2. Gonçalves $A P$, Pla AL, Rodolfo $B$, Pardo FN, Correa MB, Moraes RR. Top-100 most cited dental articles with authors from Brazil. Braz Dent J 2019;30:1-10.

3. Gonçalves $A P$, Porto $B L$, Rodolfo $B$, Faggion $C M$ Jr, Agostini $B A$, Sousa-Neto MD, et al. Brazilian articles in top-tier dental journals and influence of international collaboration on citation rates. Braz Dent J 2019:30:307-316.

4. Rosa WL, Silva TM, Lima GS, Silva AF, Piva E. Fifty years of Brazilian Dental Materials Group: scientific contributions of dental materials field evaluated by systematic review. J Appl Oral Sci 2016;24:299-307.

5. Estrela C, Estrela CR, Barbin EL, Spanó JC, Marchesan MA, Pécora JD. Mechanism of action of sodium hypochlorite. Braz Dent J 2002;13:113117.

6. Estrela C, Bammann LL, Estrela CR, Silva RS, Pécora JD. Antimicrobial and chemical study of MTA, Portland cement, calcium hydroxide paste, Sealapex and Dycal. Braz Dent J 2000;11:3-9.

7. Novaes AB Jr, de Souza SL, de Barros RR, Pereira KK, lezzi G, Piattelli A. Influence of implant surfaces on osseointegration. Braz Dent J 2010;21:471-481.

8. Estrela C, Sydney GB, Bammann LL, Felippe Júnior O. Mechanism of action of calcium and hydroxyl ions of calcium hydroxide on tissue and bacteria. Braz Dent J 1995:6:85-90.

9. Aidar M, Line SR. A simple and cost-effective protocol for DNA isolation from buccal epithelial cells. Braz Dent J 2007;18:148-152.
10. Holland R, de Souza V, Murata SS, Nery MJ, Bernabé PF, Otoboni Filho $J A$, et al. Healing process of dog dental pulp after pulpotomy and pulp covering with mineral trioxide aggregate or Portland cement. Braz Dent J 2001:12:109-113.

11. López ME, Colloca ME, Páez RG, Schallmach JN, Koss MA, Chervonagura A. Salivary characteristics of diabetic children. Braz Dent J 2003;14:2631.

12. Holland R, de Souza V, Nery MJ, Faraco Júnior IM, Bernabé PF, Otoboni Filho $\mathrm{JA}$, et al. Reaction of rat connective tissue to implanted dentin tube filled with mineral trioxide aggregate, Portland cement or calcium hydroxide. Braz Dent J 2001;12:3-8.

13. Queiroz CS, Hara AT, Paes Leme AF, Cury JA. pH-Cycling models to evaluate the effect of low fluoride dentifrice on enamel de- and remineralization. Braz Dent J 2008;19:21-27.

14. Cury JA, Tenuta LM, Ribeiro CC, Paes Leme AF. The importance of fluoride dentifrices to the current dental caries prevalence in Brazil. Braz Dent J 2004:15:167-174.

15. Gajewski VE, Pfeifer CS, Fróes-Salgado NR, Boaro LC, Braga RR. Monomers used in resin composites: Degree of conversion, mechanical properties and water sorption/solubility. Braz Dent J 2012;23:508-514.

16. Estrela C, Alencar AH, Kitten GT, Vencio EF, Gava E. Mesenchymal stem cells in the dental tissues: Perspectives for tissue regeneration. Braz Dent J 2011;22:91-98.

17. Rosa AL, Beloti MM. Effect of cpTi surface roughness on human bone marrow cell attachment, proliferation, and differentiation. Braz Dent J 2003;14:16-21.

18. Shinohara $E H$, Martini $M Z$, de Oliveira Neto $H G$, Takahashi A. Oral myiasis treated with ivermectin: case report. Braz Dent J 2004;15:7981.

19. Vasconcelos LC, Sampaio FC, Sampaio MC, Pereira Mdo S, Higino JS, Peixoto MH. Minimum inhibitory concentration of adherence of Punica granatum Linn (pomegranate) gel against S. mutans, S. mitis and C. albicans. Braz Dent J 2006;17:223-227.

20. Ladalardo TC, Pinheiro A, Campos RA, Brugnera Júnior $A$, Zanin $\mathrm{F}$, Albernaz $\mathrm{PL}$, et al. Laser therapy in the treatment of dentine hypersensitivity. Braz Dent J 2004;15:144-150.

21. Garcia EJ, Oldoni TL, Alencar SM, Reis A, Loguercio AD, Grande RH. Antioxidant 22. activity by DPPH assay of potential solutions to be applied on bleached teeth. Braz Dent J 2012;23:22-27.

22. Gomes BP, Vianna ME, Zaia AA, Almeida JF, Souza-Filho FJ, Ferraz CC. Chlorhexidine in endodontics. Braz Dent J 2013;24:89-102.

23. Zogheib LV, Bona AD, Kimpara ET, McCabe JF. Effect of hydrofluoric acid etching duration on the roughness and flexural strength of a lithium disilicate-based glass ceramic. Braz Dent J 2011;22:45-50.

24. Pinheiro AL, Limeira Júnior Fde $A$, Gerbi ME, Ramalho LM, Marzola $C$, Ponzi EA. Effect of low level laser therapy on the repair of bone defects grafted with inorganic bovine bone. Braz Dent J 2003;14:177-181.

25. Pécora JD, Woelfel JB, Sousa Neto MD, Issa EP. Morphologic study of the maxillary molars. Part II: Internal anatomy. Braz Dent J 1992;3:5357.

26. Nunes VH, Silva RG, Alfredo $E$, Sousa-Neto MD, Silva-Sousa YT. Adhesion of epiphany and $\mathrm{AH}$ plus sealers to human root dentin treated with different solutions. Braz Dent J 2008;19:46-50.

27. Durack $C$, Patel $\mathrm{S}$. Cone beam computed tomography in endodontics. Braz Dent J 2012;23:179-191.

28. Estrela C, Ribeiro RG, Estrela CR, Pécora JD, Sousa-Neto MD. Antimicrobial effect of $2 \%$ sodium hypochlorite and $2 \%$ chlorhexidine tested by different methods. Braz Dent J 2003;14:58-62.

29. Demarco FF, Conde MC, Cavalcanti BN, Casagrande L, Sakai VT, Nör JE. Dental pulp tissue engineering. Braz Dent J 2011;22:3-13.

30. da Silva WJ, Seneviratne J, Parahitiyawa N, Rosa EA, Samaranayake LP, Del Bel Cury AA. Improvement of XTT assay performance for studies involving Candida albicans biofilms. Braz Dent J 2008;19:364-369.

31. Siqueira JF Jr, Rôças IN. Bacterial pathogenesis and mediators in apical periodontitis. Braz Dent J 2007;18:267-280.

32. Pereira JV, Bergamo DC, Pereira JO, França Sde C, Pietro RC, SilvaSousa YT. Antimicrobial activity of Arctium lappa constituents against microorganisms commonly found in endodontic infections. Braz Dent J 2005;16:192-196. 
33. Oliveira MG, Xavier CB, Demarco FF, Pinheiro AL, Costa AT, Pozza DH. Comparative chemical study of MTA and Portland cements. Braz Dent J 2007;18):3-7

34. Holland R, Souza Vd, Nery MJ, Faraco Júnior IM, Bernabé PF, Otoboni Filho $\mathrm{JA}$, et al. Reaction of rat connective tissue to implanted dentin tubes filled with a white mineral trioxide aggregate. Braz Dent J 2002;13:23-26

35. Letchford A, Moat HS, Preis T. The advantage of short paper titles. $R$ Soc Open Sci 2015;2:150266.

36. Cronin B, Shaw D. Citation, funding acknowledgement and author nationality relationships in four information science journals. J Docum 1999;55:402-408.

37. Bassani R, Pereira GK, Page MJ, Tricco AC, Moher D, Sarkis-Onofre R.
Systematic reviews in dentistry: Current status, epidemiological and reporting characteristics. J Dent 2019;82:71-84.

38. Ioannidis JP. The mass production of redundant, misleading, and conflicted systematic reviews and meta-analyses. Milbank 0 2016;94:485-514.

39. Sarkis-Onofre R, Pereira-Cenci T, Bassani R, Page MJ, Tricco AC, Moher D, et al. Journal of Evidence-Based Healthcare 2019; doi:10.17267/2675021Xevidence.v1i2.2506.

Received December 18, 2019 Accepted January 9, 2020 